\title{
Glutamate-Gated Inhibitory Currents of Central Pattern Generator Neurons in the Lobster Stomatogastric Ganglion
}

\author{
Thomas A. Cleland and Allen I. Selverston \\ Biology Department, University of California at San Diego, La Jolla, California 92093-0357
}

Inhibitory glutamatergic neurotransmission is an elemental "building block" of the oscillatory networks within the crustacean stomatogastric ganglion (STG). This study constitutes the initial characterization of glutamatergic currents in isolated STG neurons in primary culture. Superfusion of $1 \mathrm{~mm}$ L-glutamate evoked a current response in 45 of 65 neurons examined. The evoked current incorporated two kinetically distinct components in variable proportion: a fast desensitizing component and a slower component. The current was mediated by an outwardly rectifying conductance increase and reversed at $-\mathbf{4 8 . 8} \pm \mathbf{5 . 3}$ $\mathrm{mV}$. Reducing the external chloride concentration by $50 \%$ deflected the glutamate equilibrium potential $\left(E_{\text {glu }}\right)$ by +14 $\mathrm{mV}$, while increasing external potassium threefold shifted $E_{\text {glu }}$ by up to $+6 \mathrm{mV}$. Ibotenic acid fully activated both components of the glutamate response. Saturating concentrations of glutamate completely occluded neuronal responses to ibotenic acid, indicating that ibotenic acid was activating the same receptor(s) as glutamate. Millimolar concentrations of quisqualic acid, kainate, AMPA, and NMDA each failed to evoke any response. Picrotoxin $\left(10^{-4}\right.$ M) completely blocked the glutamate response. Niflumic acid $(100 \mu \mathrm{M})$ blocked $>80 \%$ of the desensitizing component and $\sim \mathbf{5 0} \%$ of the sustained component. Reduction or elimination of extracellular calcium did not abolish the response.

This study extends the ionic and pharmacological analysis of glutamatergic conductances in STG neurons. The currents described are consistent with glutamatergic inhibitory synaptic and agonist-evoked responses previously described in situ. We discuss their pharmacology, ionic mechanisms, and functional significance.

[Key words: niflumic acid, lobster, stomatogastric, crustacean, reciprocal inhibition, glutamate, chloride current, potassium current, central pattern generator, voltage dependence]

The crustacean stomatogastric ganglion (STG) contains neural elements of at least two central pattern generator (CPG) circuits (Fig. 1A), which control rhythmic movements of the foregut

\footnotetext{
Received Mar. 28, 1995; revised May 15, 1995; accepted June 6, 1995.

Our thanks to R. C. Elson, W.-D. Krenz, C. M. E. Hempel, and Y. I. Arshavsky for critical reading of the manuscript, and I. Hsieh for valuable computer support. This work was supported by the National Institutes of Health Program Project Grant PO1NS25916 to A.I.S, and a National Scicnec Foundation predoctoral fellowship to T.A.C.

Correspondence should be addressed to Thomas A. Cleland, UCSD Biology Department 0357, 9500 Gilman Drive, La Jolla, CA 92093-0357.

Copyright (C) 1995 Society for Neuroscience 0270-6474/95/156631-09\$05.00/0
}

(Johnson and Hooper, 1992), and have served as model systems for understanding the function of biological neural networks (Kristan, 1980; Getting, 1989). Inhibitory glutamatergic synaptic transmission is a major building block of the reciprocal inhibitory pairs and recurrent cyclic inhibitory chains of the neurons that comprise these oscillatory CPGs (Marder and PaupardinTritsch, 1978; Marder and Eisen, 1984). The chemical modulation of these glutamatergic synapses contributes heavily to control of oscillatory phase relationships among the participating neurons (Johnson et al., 1994), and changes in such phase relationships in turn directly mediate changes in behavioral output (Heinzel et al., 1993).

The glutamatergic IPSP in situ is primarily dependent on chloride, but also sometimes exhibits a smaller potassium dependence which has not been separable from the chloride-mediated response in Panulirus interruptus (Marder, 1987). These "fast" glutamatergic IPSPs are blocked by picrotoxin (Eisen and Marder, 1982; Marder and Eisen, 1984), and are similar in reversal potential and ionic dependence to the responses elicited by iontophoretically applied glutamate (Marder and Paupardin-Tritsch, 1978; Bidaut, 1980; Eisen and Marder, 1982). The ionic and pharmacological profile of this receptor clearly distinguish it from the major vertebrate glutamate receptor families; however, the chloride-mediated current resembles the currents mediated by glutamate-gated chloride channels in Aplysia neurons (Ikemoto and Akaike, 1988; Sawada et al., 1984; King and Carpenter, 1989), extrajunctional glutamate receptors in locust and American lobster muscles (Cull-Candy, 1976; Lingle and Marder, 1981), and the cloned GluCl ionotropic glutamate receptor from C. elegans (Cully et al., 1994).

This study describes the glutamate-gated membrane currents in isolated, cultured STG neurons under two-electrode voltage clamp in order to lay the groundwork for detailed studies of the glutamate receptor and its modulation at the cellular and network levels. Cultured neurons are advantageous for these studies in that they are electrotonically compact, isolated from other neurons which might evoke secondary effects, and accessible to manipulations such as focal perfusion. In this initial characterization, we describe receptor pharmacolugy and ionic dependencies, as well as an intrinsic voltage dependence of receptor activation which carries possible implications for its role in the stomatogastric neural network.

Some of these data were previously published in abstract form (Cleland and Selverston, 1994).

\section{Materials and Methods}

Cell culture. Adult Pacific spiny lobsters, Panulirus interruptus, were captured wild and kept in running seawater until use. The stomatogastric ganglion (STG) was removed, desheathed, pinned to a Sylgard-lined 
A
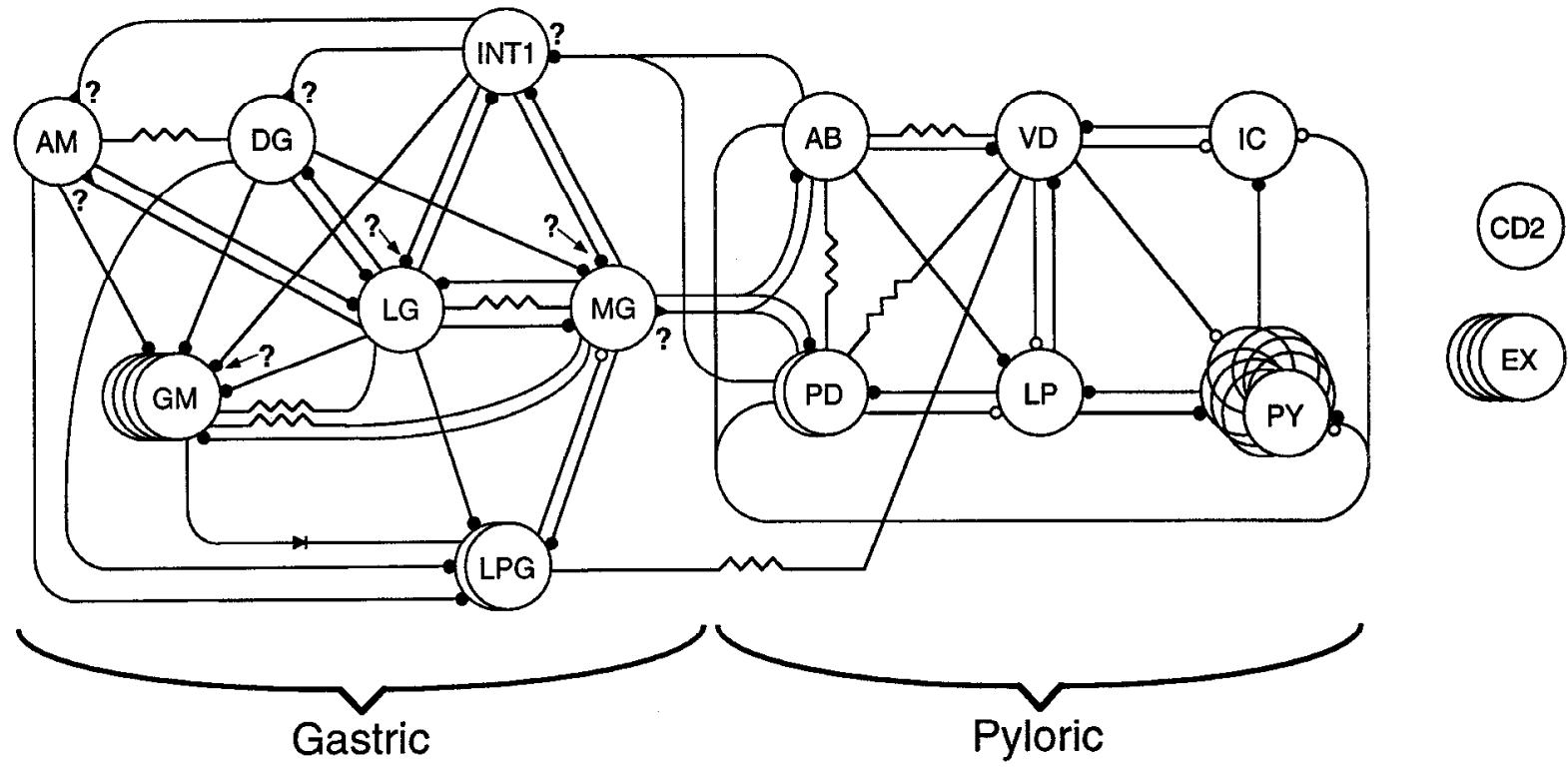

B
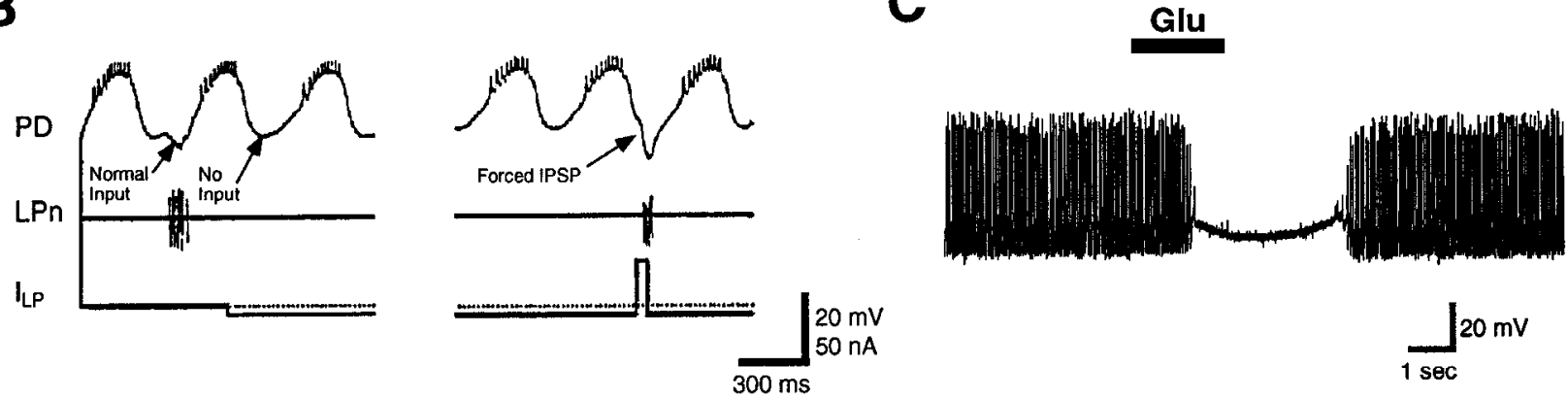

Figure 1. Functional role of the inhibitory glutamate receptor. $A$, Circuit diagram of the gastric and pyloric networks and other cells of the stomatogastric ganglion (STG). Most neurons in this central pattern generator are glutamatergic ( $A B, I C, P Y, L P, L G, M G, D G, A M$, and probably Int1). All pyloric neurons and nearly all gastric neurons receive glutamatergic inhibitory synapses from other STG neurons in situ. Solid circles indicate inhibitory glutamatergic synapses; open circles indicate inhibitory cholinergic synapses. Question marks indicate presumed glutamatergic synapses, both inhibitory (circles) and excitatory (triangles). Electrotonic synapses are depicted by the resistor symbol; rectifying electrotonic synapses by the diode symbol. Note that there are two PD, two LPG, four GM, and eight PY neurons within the STG. The stomatogastric ganglion also contains one CD2 neuron (a member of the interganglionic cardiac sac network) and an estimated four EX neurons which are not well understood. $B$, Recording from an in situ ganglionic preparation from Panulirus interruptus demonstrating the effect of a glutamatergic synapse between identified neurons in the STG. The LP neuron (depicted by the spikes recorded from its output nerve, the LPn) normally inhibits the PD neuron phasically via a glutamatergic synapse. This inhibition can be removed by hyperpolarizing LP (note the injection of hyperpolarizing current in the $I_{\mathrm{LP}}$ trace), and a depolarizing pulse into LP can evoke a glutamatergic "forced IPSP" in PD (figure modified from Herterich, 1992). $C$, Glutamate application hyperpolarizes a tonically spiking, isolated, cultured STG neuron, thereby terminating action potential generation. A steady current injection of $+2 \mathrm{nA}$ was required in order to elicit tonic spiking in the neuron depicted.

dish, and incubated at room temperature for $1 \mathrm{hr}$ in $2 \mathrm{mg} / \mathrm{ml}$ subtilisin (Subtilisin Carlsberg, a nonspecific protease; Sigma) dissolved in Panulirus saline. After proteolysis, the ganglion was washed for 1-2 $\mathrm{hr}$ in maintenance medium or Panulirus saline, at $15^{\circ} \mathrm{C}$ or room temperature. These variations in wash parameters did not correlate with any observed variability of cellular properties. Individual neurons were removed from the ganglion by gentle suction and plated individually into $35 \mathrm{~mm} \mathrm{Fal-}$ con Primaria culture dishes in sterile maintenance medium. Recordings were made from cells after $3-4 \mathrm{~d}$ in culture, by which time cells had adhered securely to the substrate and most had extended short processes from the neurite stump, or occasionally from the soma. Incubation temperature $\left(15^{\circ} \mathrm{C}\right.$ or room temperature) did not noticeably influence glutamate response properties.

Media. Panulirus saline was prepared as described in Mulloney and Selverston (1974). Standard Panulirus maintenance medium (PMM) was prepared from full-strength Leibovitz-15 medium (Sigma powder) with all common ions supplemented to Panulirus saline concentrations, except $\mathrm{NaCl}$ which was slightly reduced (to $446 \mathrm{~mm}$ ) from its Panulirus saline concentration in order to osmotically balance the added ingredients of L-15. The final recipe for 1 liter of PMM was: $14.8 \mathrm{gm} \mathrm{L}-15$ powder, $18.07 \mathrm{gm} \mathrm{NaCl}, 0.55 \mathrm{gm} \mathrm{KCl}, 1.82 \mathrm{gm} \mathrm{CaCl}_{2} \cdot 2 \mathrm{H}_{2} 0,0.612 \mathrm{gm}$ $\mathrm{MgSO}_{4}, 0.56 \mathrm{gm} \mathrm{Na} \mathrm{SO}_{4}, 1.19 \mathrm{gm}$ HEPES acid, $1.15 \mathrm{gm}$ TES, and 3 gm D-glucose. Final salt concentrations (including the contributions from L-15 powder) were $446 \mathrm{mM} \mathrm{NaCl}, 12.7 \mathrm{mM} \mathrm{KCl}, 13.7 \mathrm{mM}$ $\mathrm{CaCl}_{2} \cdot 2 \mathrm{H}_{2} 0,5.9 \mathrm{~mm} \mathrm{MgSO}, 3.91 \mathrm{mM} \mathrm{Na}_{2} \mathrm{SO}_{4}, 5.0 \mathrm{~mm}$ HEPES acid, $5.0 \mathrm{~mm}$ TES, and $16.7 \mathrm{~mm} \mathrm{D}$-glucose. Penicillin-streptomycin (final concentrations: $100 \mathrm{U} / \mathrm{ml}$ penicillin, $0.1 \mathrm{mg} / \mathrm{ml}$ streptomycin) was also added to the stock solution. PMM was brought to $\mathrm{pH}=7.5$ with $\mathrm{HCl}$ / $\mathrm{NaOH}$, filter-sterilized through Corning $0.22 \mu \mathrm{M}$ nylon filters, and refrigerated until use. 
Recording and analysis. Culture dishes were mounted on a Nikon Diaphot TMD inverted microscope and the neurons were visualized with Hoffman modulation optics. Agonists were delivered by wholecell focal superfusion. Agonists were flowed steadily past the cell from a focal superfusion pipette to a focal uutflow (suction) pipette. To deliver the agonist, a hydrostatic pressure pulse was delivered to the superfusion pipette; this expanded the arc of agonist flow so as to encompass the entire cell. Fast green $(0.05 \%$ by weight; added to the focal perfusant), which had no observable physiological effect at the concentrations used, was used to visually confirm agonist application. The time delay between pressure pulse initiation and complete whole-cell perfusion was somewhat variable, but generally in the range of a few hundred milliseconds (as measured by the application of high-potassium saline). The preparation was also globally perfused at a rate of $2.5 \mathrm{ml} /$ min with agonist-free saline of the same ionic composition as the focal perfusant. In experiments involving glutamate-evoked current antagonists, the antagonist was present in both the bath saline and the perfusant, except for picrotoxin experiments in which only the bath saline contained the toxin. No calcium buffers or chelators were added to calcium-free saline. If cells exhibited sodium spike currents at depolarized potentials, these were blocked with a pulse of tetrodotoxin (TTX) before experimental manipulations were begun. 'The spike current never recovered from such a pulse during any of our experiments. Two-electrode voltage-clamp recordings were made with an Axoclamp-2A (Axon Instruments, Foster City, CA). Voltage-recording electrodes were filled with $3 \mathrm{M} \mathrm{KCl}$ and had resistances of $R_{e}=15-30 \mathrm{M} \Omega$ while current-passing electrodes had $R_{e}=8-15 \mathrm{M} \Omega$ and were filled with a solution of $0.6 \mathrm{M} \mathrm{K}_{2} \mathrm{SO}_{4}$ and $20 \mathrm{mM} \mathrm{KCl}$ in order to avoid chlorideloading the cells during voltage clamp. Offset potentials generated by altered chloride concentrations in bath saline were subtracted where appropriate. Current output was Bessel-filtered at 1-2 kHz. Data were digitized directly to disk at $2 \mathrm{kHz}$ and analyzed by computer. When motion artifacts due to perfusion onset were apparent in data traces, they were graphically removed. For all " $X \pm Y$ " terms presented in this study: $\mathrm{X}=$ arithmetic mean, $\mathrm{Y}=$ one sample standard deviation $s$.

Suppliers. L-Glutamic acid, quisqualic acid, NMDA, niflumic acid, and picrotoxin were purchased from Sigma (St. Louis, MO). Ibotenic acid, kainic acid, $\alpha$-amino-3-hydroxy-5-methyl-4-isoxazolepropionate (AMPA), and more quisqualic acid were purchased from Research Biochemicals, Inc. (Natick, MA). Tetrodotoxin (TTX) was purchased from Calbiochem (San Diego, CA). Polyvinylpyrrolidone-25 (PVP-25), a 25 $\mathrm{kDa}$ chain of pyrrolidone side rings, was manufactured by Serva and purchased from Crescent Chemical Co. (Hauppage, NY). All drugs were mixed fresh from powder on the day of the experiment, except for TTX and PTX which were kept as frozen aliquots.

\section{Results}

\section{The glutamate response is multicomponent}

Within the stomatogastric ganglion (STG), all pyloric network and most gastric network neurons receive qualitatively similar "fast" glutamatergic IPSPs (Fig. 1A,B; cf. also Marder and Eisen, 1984); there are also a small number of neurons within the STG which are not part of these two networks. In order to study the currents underlying this common synaptic response, we superfused glutamate $(1 \mathrm{mM})$ over isolated STG neurons grown in primary culture for 3-4 d. In all, 45 of $65(69 \%)$ isolated, cultured neurons studied exhibited a glutamate response. Glutamate application was able to hyperpolarize and terminate action potential generation in tonically spiking neurons (Fig. 1C), an effect analogous to that of glutamatergic synapses in situ. Under voltage clamp in cultured neurons, glutamate evoked a biphasic response whose kinetically distinct components varied in relative amplitude such that they were sometimes dramatically distinct and sometimes largely overlapped one another (Fig. 2). The fast component, when visible, was strongly and rapidly desensitizing, while the slower component's desensitization, if any, was not discernable in our experiments. The variability of the glu tamate response among different cells was consistent with the presence of two currents varying in the level of expression (i.e., total maximal membrane conductance) with respect to one an-
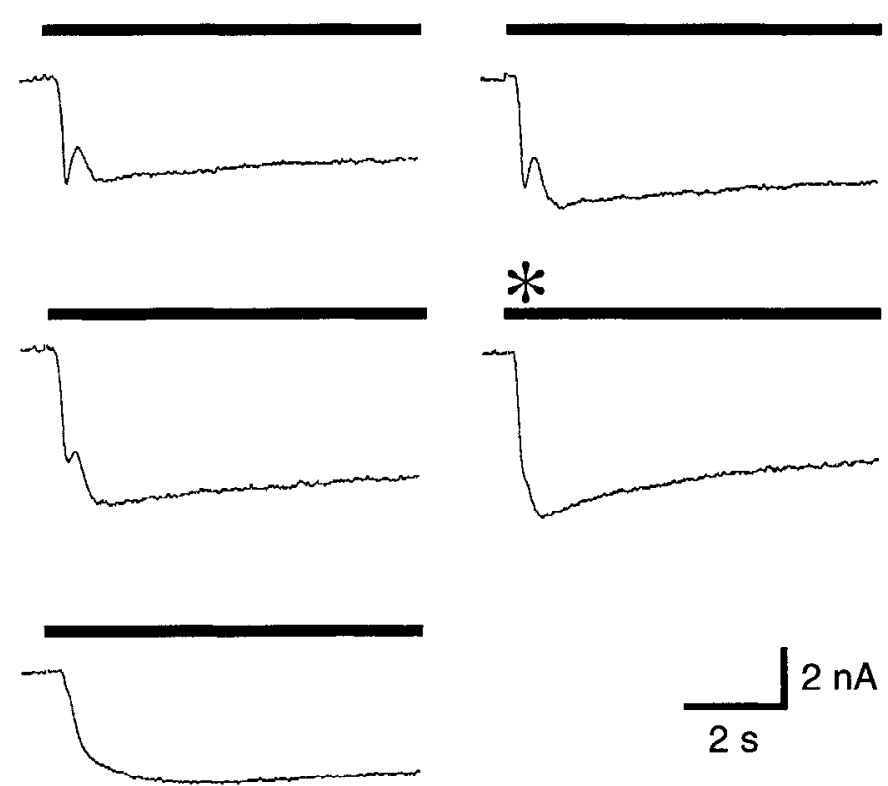

Figure 2. Variability of the glutamate response. Traces depict the currents evoked from five different voltage-clamped cells by the superfusion of $1 \mathrm{~mm} \mathrm{L-glutamate.} \mathrm{Cells} \mathrm{were} \mathrm{clamped} \mathrm{at} \mathrm{a} \mathrm{holding} \mathrm{potential}$ of $-70 \mathrm{mV}$. Bars denote the time of application of L-glutamate. Most cells tested showed responses similar to the trace denoted with an asterisk.

other; that is, the greater the proportional expression of the faster current, the faster its relative onset and the greater its temporal distinction from the slower-onset current. Alternatively, variability in agonist application time (on the order of a few hundred milliseconds to reach full concentration) may also have been responsible for the variability of observed responses, particularly as the fast component was desensitizing. The remaining 20 neurons $(31 \%)$ showed no glutamate response at all; 19 of these unresponsive neurons did display other endogenous currents, such as $I_{H}$, the hyperpolarization-activated inward current.

\section{Ion and voltage dependencies}

Glutamate application elicited an increase in total membrane conductance (Fig. 3A). This conductance increase exhibited voltage dependence, increasing with membrane depolarization (Fig. $3 B)$, and reversed at $-48.8 \pm 5.3 \mathrm{mV}(n=20)$. When the two components of the glutamate response were distinct, they reliably reversed within a few millivolts of each other, at $-48.7 \pm$ $5.3 \mathrm{mV}$ (predominantly fast; $n=11$ ) and $-49.8 \pm 5.6 \mathrm{mV}$ (predominantly slow; $n=11$ ), an insignificant difference.

Reducing external chloride concentrations by $50 \%$ (substituted with Na-methanesulfonate) shifted the glutamate reversal potential by $10-14 \mathrm{mV}$ to the positive (Fig. $4 A$ ); the Nernst prediction for a chloride electrode is a $+16 \mathrm{mV}$ shift in reversal potential, indicating that the STG glutamate response is primarily mediated by chloride. Estimated ionic activities, rather than concentrations, were used for these calculations (Robinson and Stokes, 1968; cf. Appendix 8.10, Table 10). The slope conductance of the glutamate response was found to decrease under low external chloride conditions; this suggested that Na-methanesulfonate may be effecting a slight blockade of the chloride current.

We increased external potassium concentrations with four cells and observed a shift in the equilibrium potential for glutamate of up to $+6 \mathrm{mV}$ in $3 \times\left[\mathrm{K}^{+}\right]_{o}$ saline (compensated with 
A
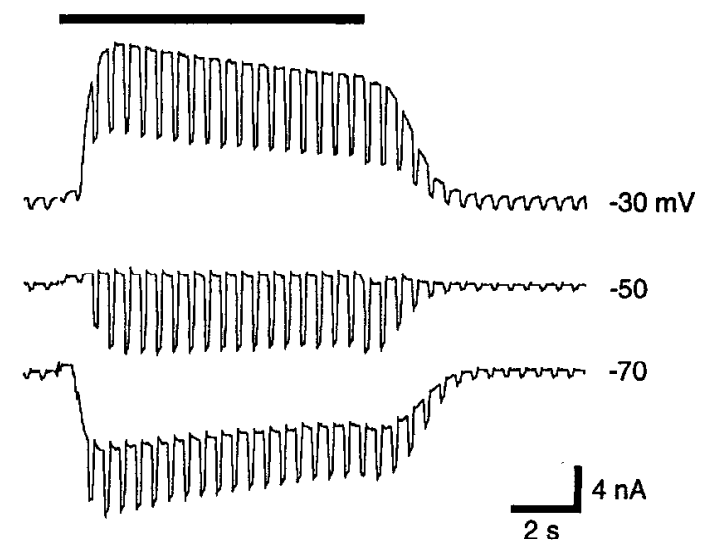

B

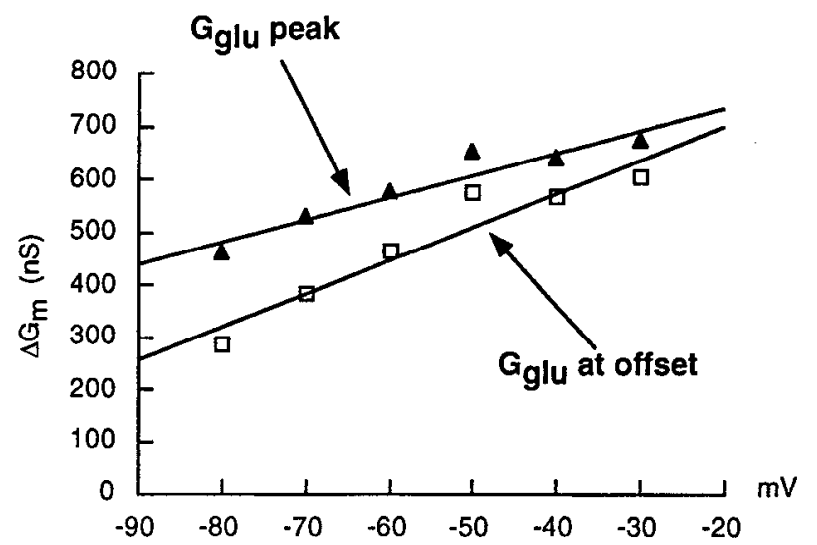

Figure 3. Outwardly rectifying membrane conductance increase in response to glutamate application. $A$, Conductance increases in response to glutamate superfusion at holding potentials of $-70,-50$, and -30 $\mathrm{mV}$ (bottom to top), as revealed by voltage steps of $-10 \mathrm{mV}$ applied at $2 \mathrm{~Hz}$. Note that the glutamate-evoked conductance increase exhibits a voltage dependence. $(n=3)$. B, Conductance-voltage $(G-V)$ plot of the voltage dependence of the glutamate-evoked conductance. Measurements of both peak and sustained responses are shown. Sustained currents were measured at the end of glutamate application. The lines fit to the data are intended to highlight the voltage dependence and not to imply linearity; the change in slope at $-50 \mathrm{mV}$ may indicate the maximum whole-cell glutamatergic conductance. $\left(G_{\text {glu }}\right.$ : glutamateevoked membrane conduclance).

reduced $\left[\mathrm{Na}^{+}\right]$; Fig. $\left.4 B, C\right)$. A $+6 \mathrm{mV}$ shift is $21 \%$ of that predicted for a potassium electrode. The picrotoxin-sensitive glutamatergic IPSP in situ also exhibits a potassium dependence (Marder and Paupardin-Tritsch, 1978). However, no distinct component of the glutamatc response was observed to reverse anywhere near $E_{\mathrm{K}}$, the potassium reversal potential. The mechanisms underlying this glutamatergic potassium permeability in lobster are not yet understood.

\section{Agonist pharmacology}

Ibotenic acid induced both the peak and sustained components of the glutamate response in a manner identical to glutamate at the same concentration (Fig. $5 A, B ; n=3$ ). In order to determine whether ibotenic acid was activating the same current(s) as glutamate, summation experiments were performed. The presence of saturating concentrations ( $1 \mathrm{mM})$ of glutamate in the bath reversibly abolished the cells' response to ibotenate application
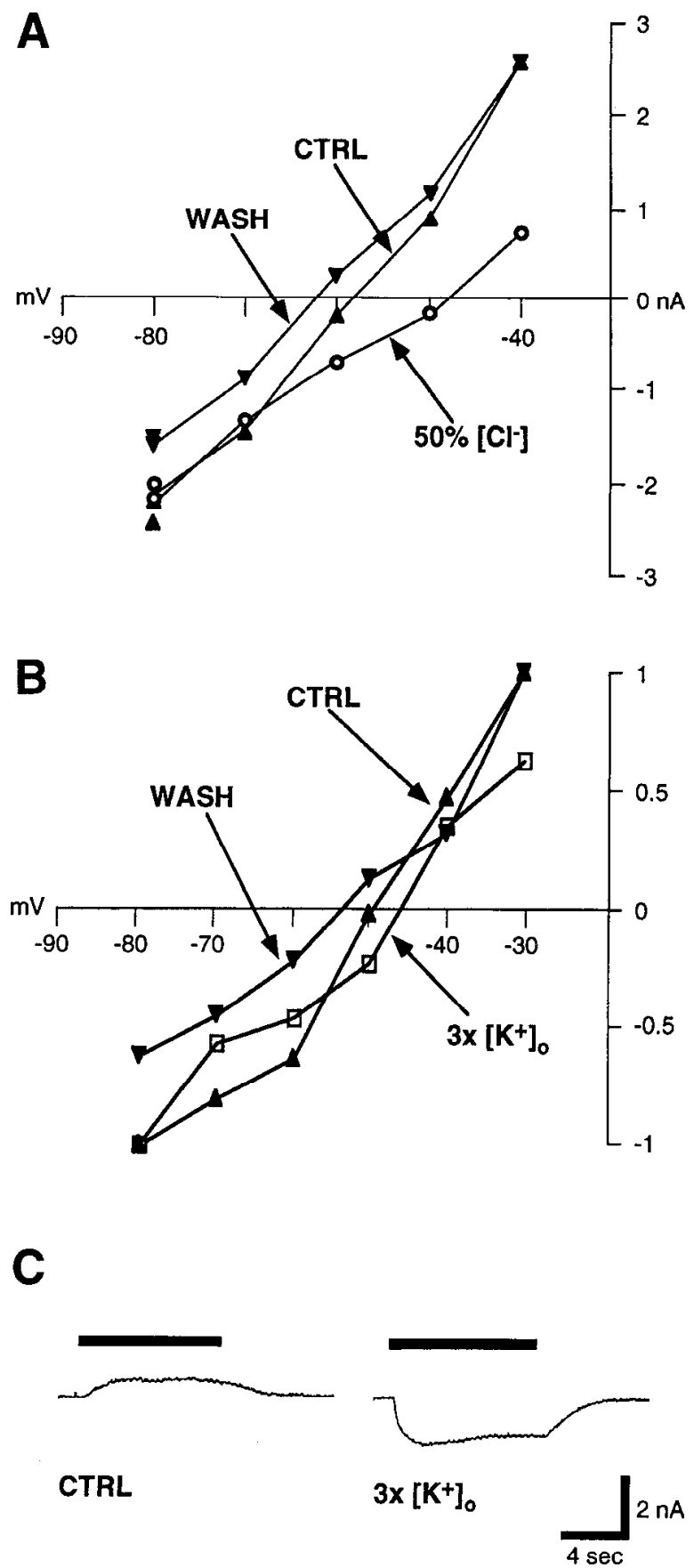

Figure 4. Ionic dependence. $A$, Reduction of external chloride by $50 \%$ (substituted by Na-methanesulfonate) shifted the glutamate reversal potential to the positive by $10-14 \mathrm{mV}(n=4)$, that is, $60-90 \%$ of the Nernst-predicted shift of $+16 \mathrm{mV}$ for a chloride current. Estimated chloride activity, not concentration, was used for these calculations. The decrease in slope conductance under low-chloride conditions suggests that Na-methanesulfonate may be a "slow permeator" of the glutamategated channels, effecting a slight blockade of the chloride current (CTRL, control). B, Increasing the external potassium concentration threefold shifted the glutamate reversal potential $\left(E_{\text {glu }}\right)$ to the right by up to $6 \mathrm{mV}$, or approximately $21 \%$ of the shift predicted for a purely $\mathrm{K}^{+}$-selective current. Data shown are the normalized, averaged responses from the two experiments (out of four) showing the highest degree of potassium dependence. Sustained current measurements are depicted, although peak current measurements exhibited a similar shift in $E_{\mathrm{glu}} . C$, Currents evoked by glutamate from a holding potential of $-50 \mathrm{mV}$ in normal and high-potassium saline, showing a resultant shift in the equilibrium potential for glutamate. 
A
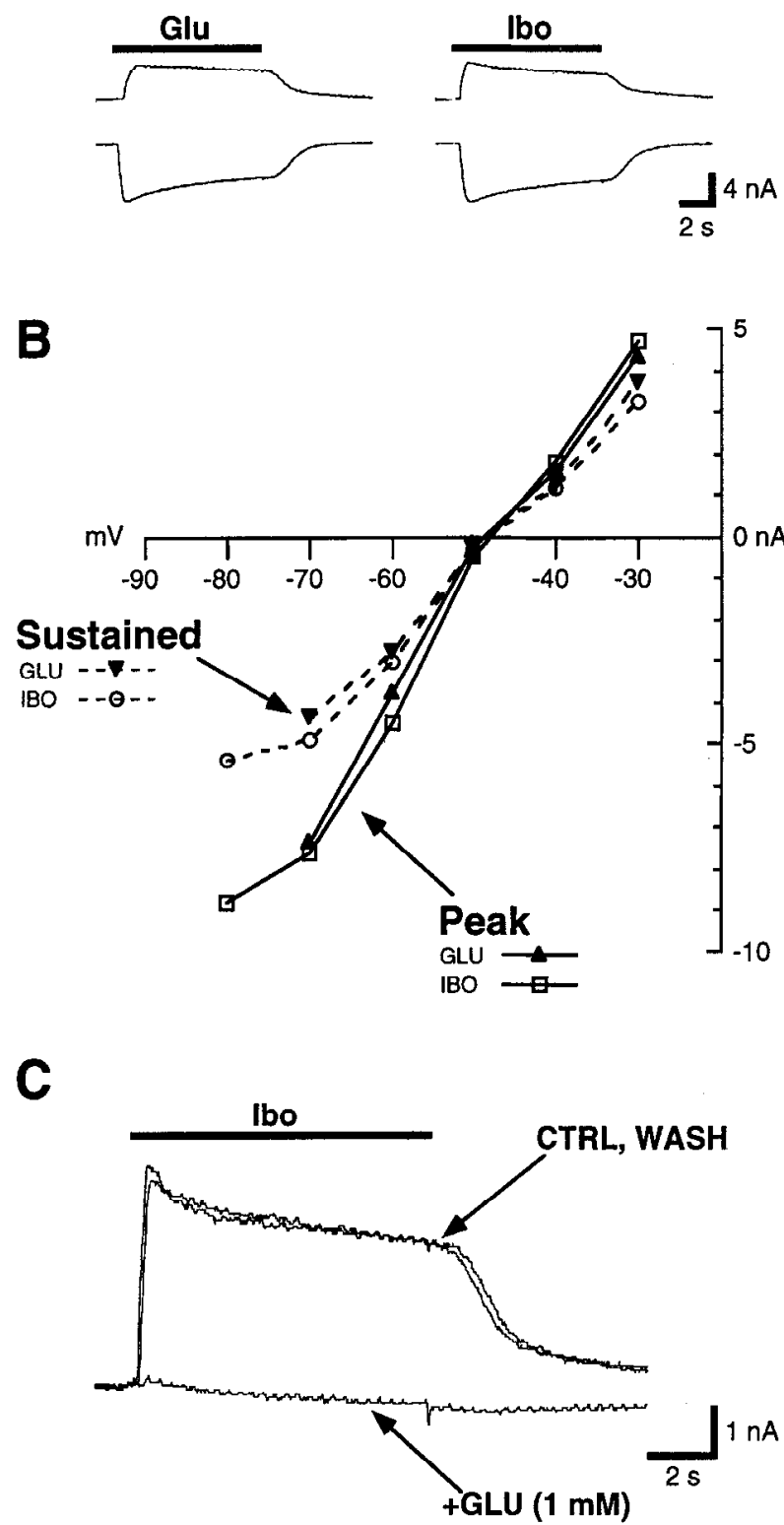

Figure 5. Effect of ibotenic acid application. A, Ibotenic acid (1 $\mathrm{mm})$ mimics the effect of equimolar glutamate upon the same neuron. Responses from holding potentials of -40 (top) and $-70 \mathrm{mV}$ are shown times of agonist application are denoted by bars. Glu, $1 \mathrm{mM} \mathrm{L-gluta-}$ mate. $I b o, 1 \mathrm{~mm}$ ibotenic acid. $(n=3) . B$, Ibotenic acid current-voltage $(I-V)$ curves overlap glutamate $I-V$ curves for both peak and sustained components. Sustained currents were measured at the end of agonist application. $C$, Bath-applied glutamate at saturating concentration (1 $\mathrm{mM}$ ) reversibly occludes the ibotenic acid response, indicating that ibotenic acid acts upon the glutamate receptor. Response shown is from a holding potential of $-40 \mathrm{mV}$ (CTRL, control).

(Fig. 5C); if ibotenate activated different receptors than glutamate, the current(s) would have summated; $200 \mu \mathrm{M}$ bath-applied glutamate only partially inhibited the ibotenic acid response (data not shown).

Millimolar concentrations of quisqualate $(n=4)$, kainate $(n=$ 2), $\alpha$-amino-3-hydroxy-5-methyl-4-isoxazolepropionate (AMPA; $n=3$ ), and NMDA; $n=2$ ), tested in cells with robust glutamate responses, never evoked any visible response at any holding potential tested (Fig. 6).
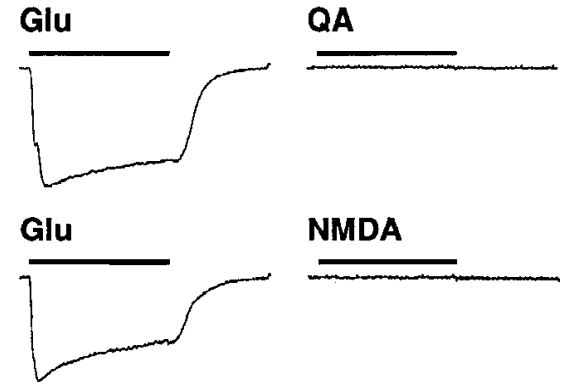

NMDA

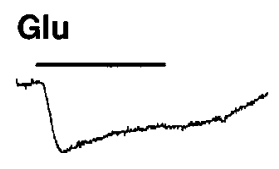

AMPA
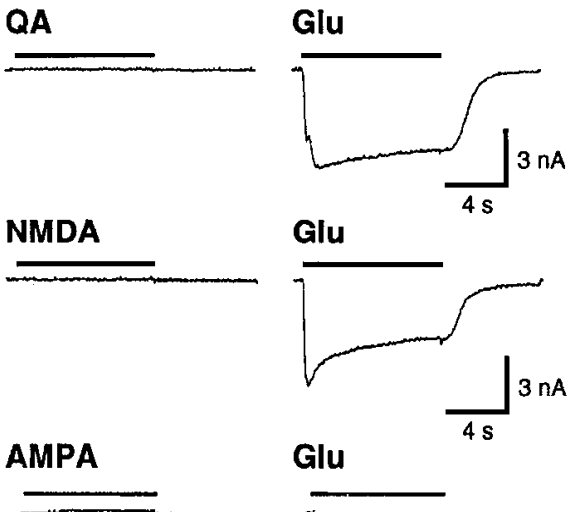

Glu
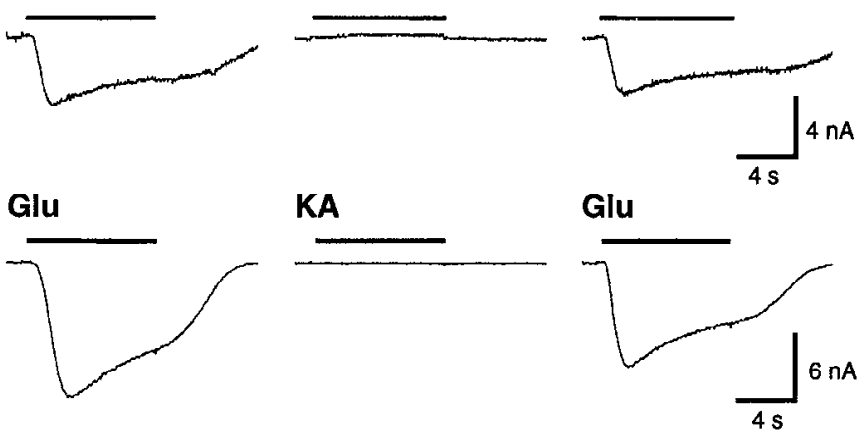

Figure 6. Agonist pharmacology. Neither $1 \mathrm{~mm}$ quisqualate (QA; $n$ $=4), 1 \mathrm{mM}$ NMDA $(n=2), 1 \mathrm{mM} \alpha$-amino-3-hydroxy-5-methyl-4isoxazolepropionate (AMPA; $n=3$ ), or $1 \mathrm{~mm}$ kainate $(K A ; n=2)$ evoked any part of the glutamate response. All cells tested exhibited robust responses to glutamate both before (left panel) and after (right panel ) application of other agonists. All traces are from holding potentials of $-70 \mathrm{mV}$.

\section{Antagonist pharmacology}

Picrotoxin (PTX), a chloride channel blocker (Newland and Cull-Candy, 1992; Pribilla et al., 1992), blocks inhibitory glutamatergic synapses in the STG in situ (Marder, 1987). We tested its effect on the glutamate response of isolated cells; $10 \mu \mathrm{M}$ PTX attenuated the glutamate response, while $100 \mu \mathrm{M}$ PTX abolished it (Fig. 7; $n=2$ ). Unlike the intact STG preparation, in which PTX blockade is difficult to reverse at these concentrations, 20 min wash at $2.5 \mathrm{ml} / \mathrm{min}$ restored an appreciable fraction of the response in cultured cells.

Niflumic acid $(100 \mu \mathrm{M})$, generally considered a chloride channel antagonist (see Discussion), blocked most of the transient

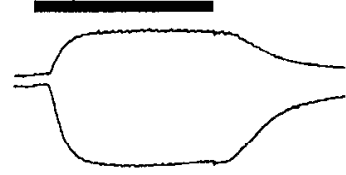

Control

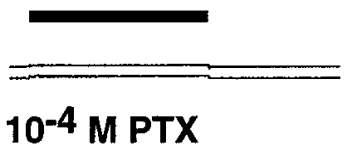

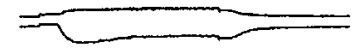

$10^{-5}$ M PTX

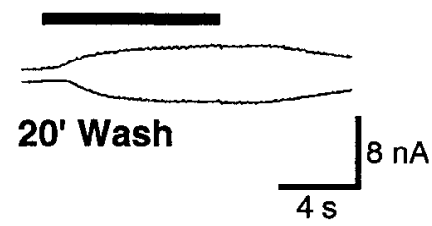

Figure 7. Effect of picrotoxin (PTX); $10 \mu \mathrm{M}$ PTX partially blocks the glutamatergic response, while $100 \mu \mathrm{M}$ PTX blocks it entirely $(n=2)$. PTX block was partially reversible in cell culture. Responses shown are from holding potentials of $-40(t o p)$ and $-70 \mathrm{mV}$. 
A

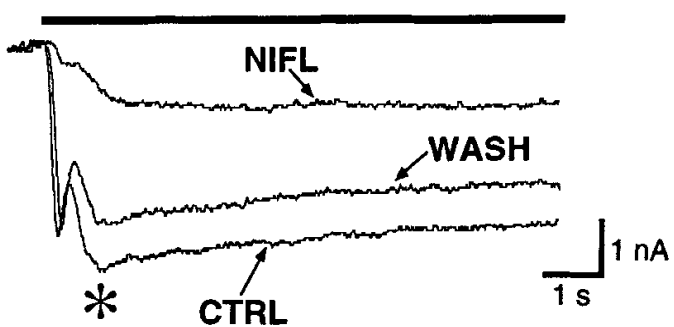

B
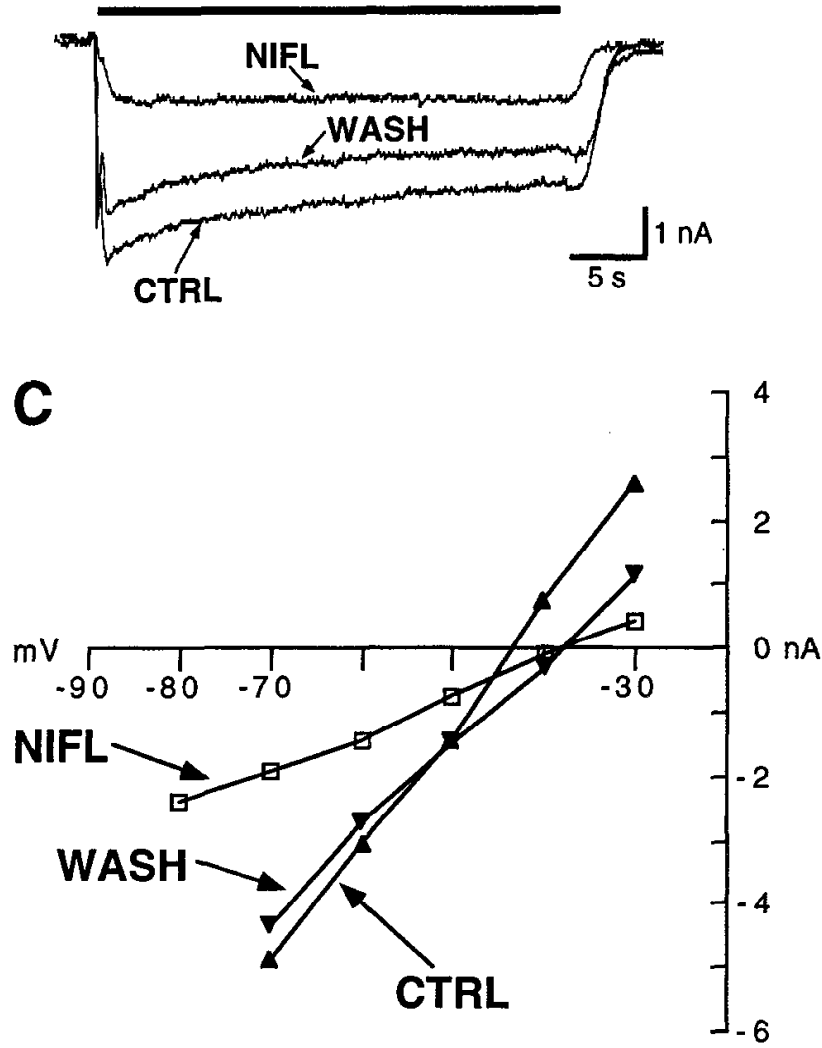

Figure 8. Blocking effect of niflumic acid. A, Effect of $100 \mu \mathrm{M}$ niflumic acid on the neuronal glutamate response. Niflumic acid blocked the distinct transient component by more than $80 \%$, and the sustained component by approximately $50 \%$. The asterisk denotes the "late peak" of the evoked current, presumably incorporating both fast transient and slow current components, which is depicted in $C .(n=3)$. Responses shown are from a holding potential of $-70 \mathrm{mV}$ (NIFL, in the presence of niflumic acid; $C T R L$, control). $B$, Extended recording of the same data as in $A$. Niflumic acid reduced the degrec of response desensitization from $36 \%$ to a negligible $3 \%$. C, Current-voltage plot of the niflumic acid sensitivity of the late-peak glutamate response (denoted in $A$ with an asterisk).

component of the glutamate response ( $>80 \%$; Fig. $8 A$ ) as well as an average of about $50 \%$ of the total sustained response; it also abolished response desensitization (Fig. 8B). The reversal potential of the total response at the late peak, denoted by an asterisk in Figure $8 A$ (at which both temporal components of the response are simultaneously active) was not affected by the niflumic acid blockade (Fig. 8C).
A CTRL

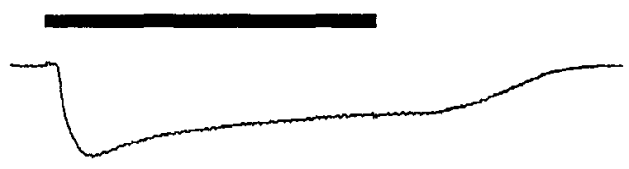

\section{B Ca++Free (+ 2mM PVP-25)}

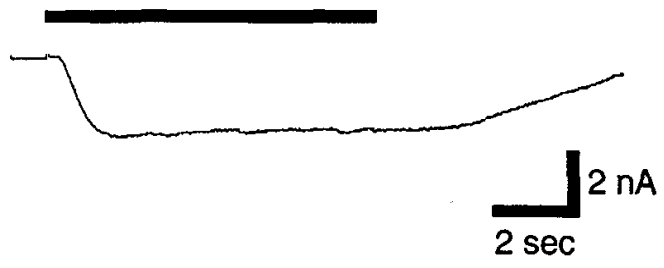

Figure 9. Influx of extracellular calcium is not necessary to evoke the glutamate response. $A$, Glutamate-evoked currents in control saline at a holding potentials of $-70 \mathrm{mV}$. $B$, Glutamate-evoked currents in calcium-free saline. Due to the general toxicity of a zero-calcium environment to these neurons, $2 \mathrm{mM}$ polyvinylpyrrolidone-25 (PVP-25) was added to the calcium-free saline in order to preserve the integrity of the plasma membrane (Raditsch and Witzemann, 1994). The absence of extracellular calcium did not abolish the glutamate-evoked response. ( $n$ $=4)$.

\section{Effect of extracellular calcium}

Niflumic acid is an established antagonist, in several systems, of calcium-dependent chloride channels which are dependent upon calcium influx across the plasma membrane for activation (Leonard and Kelso, 1990; White and Aylwin, 1990; SanchezVives and Gallego, 1994). We removed extracellular calcium in order to asscss whether this response involved calcium-dependent chloride currents dependent upon external calcium influx. As a low or zero-calcium environment was typically toxic to these neurons, $2 \mathrm{mM}$ polyvinylpyrrolidone-25 (PVP-25) was added to the calcium-free saline in order to retard the breakdown of the plasma membrane (Raditsch and Witzemann, 1994). The glutamate response was not abolished in the absence of calcium, ruling out this model (Fig. 9), although the degree of apparent desensitization was reduced. The glutamate response also persisted in PVP-free saline containing $10 \%$ of the normal calcium concentration, substituted with magnesium, and including $1 \mathrm{mM}$ cadmium in order to prevent calcium influx through voltagedependent calcium channels at the more depolarized holding potentials (data not shown).

\section{Discussion}

\section{Cell culture and identification}

The stomatogastric network preparation, like most in situ preparations, is composed of cells with long and complex arborizations (King, 1976a,b; Graubard and Wilensky, 1994; Thuma and Hooper, 1994) which prevent reliable voltage clamping of the membrane (Graubard and Hartline, 1991; Golowasch and Marder, 1992; Hartline et al., 1993; Turrigiano and Marder, 1993). While valuable information has been gained from voltage-clamp work in situ (Graubard and Hartline, 1991; Golowasch and Marder, 1992), space-clamp limitations hamper the analysis of currents expressed in the neuropil. Furthermore, the application of 
agonists to conductances expressed within the neuropil is hindered. Finally, while pharmacological blockade and photoinactivation techniques are powerful tools for isolating neurons (Miller and Selverston, 1979; Flamm and Harris-Warrick, 1986a,b; Hooper and Marder, 1987; Johnson et al., 1993a; Johnson et al., 1994), neuronal interactions mediated by the termini of descending inputs exist which cannot be removed by these means (Nusbaum et al., 1992). These problems are all abrogated by extracting neurons into primary culture. It should be noted that while the study of glutamatergic conductances per se is facilitated in culture, the electrotonic compactness of the cells used for voltage-clamp study eliminates the complexity and potential information content of differential receptor distribution. Furthermore, removal of neurons from their potentially instructive environment certainly could affect their membrane properties. These potential sources of error must be taken into account when reintegrating these data into systemic studies. Neurons for this study were not identified, as most neurons within the STG receive qualitatively similar glutamatergic IPSPs (Fig. 1).

The reversal potential for glutamatergic synapses in the intact ganglion is estimated at $-70 \pm 12 \mathrm{mV}$ in Panulirus interruptus (Marder and Eisen, 1984), whereas our data place it at $-48.8 \pm 5.3 \mathrm{mV}$. This is probably due in part to the inability in the intact ganglion to accurately control the membrane potential at distal synaptic sites (Hartline and Graubard, 1992); however, it could also incorporate a genuine shift in $E_{\mathrm{Cl}}$, perhaps due to a decreased ability of cultured neurons to regulate internal [Cl ] levels at receptor sites.

\section{Voltage dependence}

The glutamate-evoked current was mediated by an outwardly rectifying conductance increase to chloride and potassium. Notably, the GluCl $\beta$ clone from $C$. elegans, one of the putative subunits for a glutamate-gated chloride current, is a strong outward rectifier when expressed alone in oocytes (Cully et al., 1994). Outward rectification in an inhibitory postsynaptic receptor channel would act to increase the effectiveness of inhibitory synapses upon cells in their depolarized, plateau state, aiding in the termination of their burst of action potentials, while it would weaken the inhibition of neurons that were in their hyperpolarized interburst phase, thus facilitating their rebound into a plateau potential. This could contribute to a mechanism for phasespecific synaptic gain, which would be conducive to maintaining efficient and effective oscillatory "building blocks" based on reciprocal and recurrent cyclic inhibitory synapses.

\section{Comparative pharmacology}

Ibotenic acid fully mimicked the effects of glutamate upon cultured stomatogastric neurons, while quisqualate, kainate, AMPA, and NMDA evoked no response, and picrotoxin blocked the current evoked by glutamate. This pharmacological profile is similar to those of the quisqualate-insensitive neuronal chloride current in Aplysia (Sawada et al., 1984; Ikemoto and Akaike, 1988; King and Carpenter, 1989), the extrajunctional glutamate receptor of Homarus muscle (Lingle and Marder, 1981), the extrajunctional H-current of locust muscle (Cull-Candy, 1976), and the cloned channel GluCl, a chloride-selective ionotropic glutamate receptor from $C$. elegans (Cully et al., 1994). Only one quisqualate-sensitive, chloride-mediated current has been shown, in the mollusc $P$. corneus (Bolshakov et al., 1991), although a small and rare response of this type was described in Aplysia (Ikemoto and Akaike, 1988), and several molluscan neurons ex- press quisqualate-sensitive inhibitory glutamatergic currents which are mediated by potassium (Walker, 1976; Yarowsky and Carpenter, 1976; Kehoe, 1978; Katz and Levitan, 1993). In contrast, all known glutamate-gated currents in vertebrates are cation-selective and functionally excitatory (reviewed in Hollmann and Heinemann, 1994; Nakanishi and Masu, 1994). Some vertebrate retinal neurons express chloride conductances which can be activated by some glutamate analogs; these, however, may be mediated by glycine receptors (Chiba and Saito, 1994).

\section{Implications of niflumic acid blockade}

Niflumic acid, a fenamate, is a nonsteroidal antiinflammatory drug which blocks a variety of chloride currents: calcium-dependent (White and Aylwin, 1990; Hogg et al., 1994; Lamb et al., 1994; Sanchez-Vives and Gallego, 1994; Ueda and Steinberg, 1994), GABA-gated (Evoniuk and Skolnick, 1988), cAMP-gated (Hughes and Segawa, 1993), and voltage-gated (Miller and White, 1980), as well as a calcium-dependent nonselective cation current (Poronnik et al., 1992; Partridge et al., 1994) and an NMDA response (Lcrma and del Rio, 1992). Pharmacologically similar flufenamic acid blocks the GluCl glutamatergic chloride channel cloned from $C$. elegans and expressed in Xenopus oocytes (Cully et al., 1994).

In cultured STG neurons, $100 \mu \mathrm{M}$ niflumic acid blocks about $50 \%$ of the steady-state glutamatergic current and abolishes its desensitization (Fig. 8). This effect is consistent with the simple blockade of a fast, partially desensitizing chloride channel, with a niflumic acid-insensitive, nondesensitizing, slower current remaining. However, no membrane current clearly similar to such a chloride-selective, slower component has been described, although several other slow glutamatergic currents have been demonstrated (Miwa et al., 1990; Bolshakov et al., 1991; Nakanishi, 1994). Furthermore, fenamate pharmacology is complex and alternative hypotheses can not yet be ruled out. For example, niflumic acid and several other fenamates have been shown to potentiate GABAergic currents expressed in oocytes when agonist concentration is low, and yet inhibit currents elicited by high concentrations of GABA (Woodward et al., 1994). Noting that the crustacean glutamate-gated chloride current is physiologically and pharmacologically similar to the vertebrate $\mathrm{GABA}_{\mathrm{A}}$ receptor, if fenamates had the dual effect of preventing receptor desensitization and blocking ion permeation, with different functional activity coefficients for the two effects, the results could be consistent both with our data and that of Woodward et al. (1994). A second alternative is extended by recent evidence indicating that fenamates, including niflumic acid, can trigger calcium release from intracellular stores, probably from within mitochondria (Poronnik et al., 1992; Partridge et al., 1994). If this mechanism is activated in STG neurons, intracellular calcium release (or downstream effectors activated by calcium) could modulate the glutamate receptor channel, perhaps into a desensitized state. These two alternatives are also consistent with an alternate hypothesis that the kinetically distinct glutamatergic current components are derived from structural or modulatory variants of a single ionotropic receptor type; a hypothesis which is more consistent with the data from picrotoxin blockade.

\section{Implications of picrotoxin blockade}

The data from picrotoxin blockade contraindicate, though they do not rule out, the possibility that the slower, sustained component of the glutamate response is mediated by a G-proteinlinked membrane receptor. Picrotoxin (PTX; $10^{-4}$ M; Fig. 6) en- 
tirely blocked the glutamate response, including the sustained component. Recent work on the mechanism of action of picrotoxin upon vertebrate $\mathrm{GABA}_{\mathrm{A}}$ receptors has demonstrated a usedependence for PTX blockade (i.e., picrotoxin affinity for the receptor is increased in its open, ligand-bound conformation), but does not favor a simple channel blocking mechanism, suggesting instead a stabilization of an agonist-bound closed state (Newland and Cull-Candy, 1992). To the extent that this mechanism of PTX blockade implies a specificity of picrotoxin for the receptor complex rather than for an epitope common to several chloride channels, this evidence suggests that the second component is either directly dependent on the faster component for activation and/or that it is mediated by a distinct receptor with some similarity to the fast-activated receptor. One possibility is that two similar ionotropic receptors are being expressed, perhaps otherwise-identical channels which are in different, durable modulatory states, or sibling receptors with different subunit compositions that affect their kinetics (Bochet et al., 1994; Gallo et al., 1994; Lerma et al., 1994), or even channels containing RNA-edited or alternatively spliced subunit isoforms (Gallo et al., 1992; Egebjerg et al., 1994).

\section{Glutamatergic synaptic modulation}

The central pattern generators of the STG are regulated by chemical modulation of their membrane and synaptic properties. About 15 endogenous modulators have been identified to date in the stomatogastric system which are capable of modulating the CPG (Marder and Weimann, 1992; Marder et al., 1994); several of these modulators have been shown to affect glutamatergic synaptic strengths within the stomatogastric network (Elson and Selverston, 1992, 1994; Johnson ct al., 1993b, 1994). The complexity of these synaptic modulatory mechanisms requires study of glutamate-evoked postsynaptic currents. For example, dopaminergic modulation of (ionotropic) glutamate receptors has been observed in both invertebrates (Swann et al., 1978) and vertebrates (Krizaj et al., 1994; Maguire and Werblin, 1994; Schmidt et al., 1994), and the introduction of a postsynaptic intracellular messenger can be sufficient to potentiate a synapse (Pettit et al., 1994). This basic characterization of stomatogastric glutamatergic currents begins this work

\section{References}

Bidaut M (1980) Pharmacological dissection of pyloric network of the lobster stomatogastric ganglion using picrotoxin. J Neurophysiol 44: 1089-1101.

Bochet P, Audinat E, Lambolez B, Crepel F, Rossier J, Iino M, Tsuzuki K, Otawa $S$ (1994) Subunit composition at the single-cell level explains functional properties of a glutamate-gated channel. Neuron 12: 383-388.

Bolshakov VY, Gapon SA, Magazanik LG (1991) Different types of glutamate receptors in isolated and identified neurones of the mollusc Planorbarius corneus. J Physiol (Lond) 439:15-35.

Cliba C, Saito T (1994) APB (2-amino-4-phosphonobutyric acid) activates a chloride conductance in ganglion cells isolated from newt retina. Neuroreport 5:489-492.

Cleland TA, Selverston AI (1994) Glutamatergic conductance expressed in crustacean stomatogastric neurons in primary culture. Soc Neurosci Abstr 20:1412.

Cull-Candy SG (1976) Two types of extrajunctional L-glutamate receptors in locust muscle fibres. J Physiol (Lond) 255:449-464.

Cully DF, Vassilatis DK, Liu KK, Paress PS, van der Ploeg LHT, Schaeffer JM, Arena JP (1994) Cloning of an avermectin-sensitive glutamate-gated chloride channel from Caenorhabditis elegans. Nature 371:707-711.

Egebjerg J, Kukekov V, Heinemann SF (1994) Intron sequence directs
RNA editing of the glutamate receptor subunit GluR2 coding sequence. Proc Natl Acad Sci USA 91:10270-10274.

Eisen JS, Marder E (1982) Mechanisms underlying pattern generation in lobster stomatogastric ganglion as determined by selective inactivation of identified neurons. III. Synaptic connections of electrically coupled pyloric neurons. J Neurophysiol 48:1392-1415.

Elson RC, Selverston AI (1992) Mechanisms of gastric rhythm generation in the isolated stomatogastric ganglion of spiny lobsters: bursting pacemaker potentials, synaptic interactions, and muscarinic modulation. J Neurophysiol 68:890-907.

Elson RC, Selverston AI (1994) Muscarinic modulation of excitability and synaptic output in a gastric pattern-generating neuron of the lobster stomatngastric ganglion. Soc Neurosci Abstr 20:1413.

Evoniuk G, Skolnick P (1988) Picrate and niflumate block anion modulation of radioligand binding to the gamma-aminobutyric acid/benzodiazcpine receptor complex. Mol Pharmacol 34:837-842.

Flamm RE, Harris-Warrick RM (1986a) Áminergic modulation in lobster stomatogastric ganglion. I. Effects on motor pattern and activity of neurons within the pyloric circuit. J Neurophysiol 55:847-865.

Flamm RE, Harris-Warrick RM (1986b) Aminergic modulation in lobster stomatogastric ganglion. II. Target neurons of dopamine, octopamine, and serotonin within the pyloric circuit. J Neurophysiol 55: $866-881$.

Gallo V, Upson LM, Hayes WP, Vyklicky L Jr, Winters CA, Buonanno A (1992) Molecular cloning and development analysis of a new glutamate receptor subunit isoform in cerebellum. J Neurosci 12: 10101023.

Gallo V, Wright P, McKinnon RD (1994) Expression and regulation of a glutamate receptor subunit by bFGF in oligodendrocyte progenitors. Glia 10:149-153.

Getting PA (1989) Emerging principles governing the operation of neural networks. Annu Rev Neurosci 12:185-204.

Golowasch J, Marder E (1992) Ionic currents of the lateral pyloric neuron of the stomatogastric ganglion of the crab. J Neurophysiol 67:318-331.

Graubard K, Hartline DK (1991) Voltage clamp analysis of intact stomatogastric neurons. Brain Res 557:241-254.

Graubard K. Wilensky AE (1994) Morphology of stomatogastric neurons of Cancer borealis. Soc Neurosci Abstr 20:1414.

Hartline DK, Graubard K (1992) Cellular and synaptic properties in the crustacean stomatogastric system. In: Dynamic biological networks: the stomatogastric nervous system (Harris-Warrick RM, Marder E, Selverston AI, Moulins M, eds). Cambridge, MA: MIT Press.

Hartline DK, Gassie DV, Jones BR (1993) Effects of soma isolation on outward currents measured under voltage clamp in spiny lobster stomatogastric motor neurons. J Neurophysiol 69:2056-2071.

Heinzel HG, Weimann JM, Marder E (1993) The behavioral repertoire of the gastric mill in the crab, Cancer pagurus: an in situ endoscopic and electrophysiological examination. I Neurosci 13:1793-1803.

Herterich, N (1992) Recurrent synaptic inhibition in an oscillatory neuronal network. Ph.D. thesis. University of California at San Diego.

Hogg RC, Wang Q, Large WA (1994) Action of niflumic acid on evoked and spontaneous calcium-activated chloride and potassium currents in smooth muscle cells from rabbit portal vein. $\mathrm{Br} \mathrm{J}$ Pharmacol 112:977-984.

Hollmann M, Heinemann S (1994) Cloned glutamate receptors. Annu Rev Neurosci 17:31-108.

Hooper SL, Marder E (1987) Modulation of the lobster pyloric rhythm by the peptide proctolin. J Neurosci 7:2097-2112.

Hughes BA, Segawa Y (1993) cAMP-activated chloride currents in amphibian retinal pigment epithelial cells. J Physiol (Lond) 466:749766.

Ikemoto Y, Akaike N (1988) The glutamate-induced chloride current in Aplysia neurones lacks pharmacological properties seen for excitatory responses to glutamate. Eur J Pharmacol 150:313-318.

Johnson BR, Hooper SL (1992) Overview of the stomatogastric nervous system. In: Dynamic biological networks: the stomatogastric nervous system (Harris-Warrick RM, Marder E, Selverston AI, Moulins M, eds). Cambridge, MA: MIT Press.

Johnson BR, Peck JH, Harris-Warrick RM (1993a) Amine modulation of electrical coupling in the pyloric network of the lobster stomatogastric ganglion. J Comp Physiol A 172:715-732.

Johnson BR, Peck JH, Harris-Warrick RM (1993b) Dopamine induces sign reversal at mixed chemical-electrical synapses. Brain Res 625 : $159-164$. 
Johnson BR, Peck JH, Harris-Warrick RM (1994) Differential modulation of chemical and electrical components of mixed synapses in the lobster stomatogastric ganglion. J Comp Physiol A 175:233-249.

Katz PS, Levitan IB (1993) Quisqualate and ACPD are agonists for a glutamate-activated current in identified Aplysia neurons. J Neurophysiol 69:143-150.

Kehoe J (1978) Transformation by concanavalin A of the response of molluscan neurones to L-glutamate. Nature 274:866-869.

King DG (1976a) Organization of crustacean neuropil. I. Patterns of synaptic connections in lobster stomatogastric ganglion. J Neurocytol 5:207-237

King DG (1976b) Organization of crustacean neuropil. II. Distribution of synaptic contacts on identified motor neurons in lobster stomatogastric ganglion. J Neurocytol 5:239-266.

King WM, Carpenter DO (1989) Voltage-clamp characterization of $\mathrm{Cl}$ conductance gated by GABA and L-glutamate in single neurons of Aplysia. J Neurophysiol 61:892-899.

Kristan WB (1980) Generation of rhythmic motor patterns. In: Information processing in the nervous system (Pinsler HM, Willis WD Jr, eds). New York: Raven.

Krizaj D, Akopian A, Witkovsky P (1994) The effects of L-glutamate AMPA, quisqualate, and kainate on retinal horizontal cells depend on adaptational state: implications for rod-cone interactions. J Neurosci 14:5661-5671.

Lamb FS, Volk KA, Shibata EF (1994) Calcium-activated chloride current in rabbit coronary artery myocytes. Circ Res 75:742-750.

Leonard JP, Kelso SR (1990) Apparent desensitization of NMDA responses in Xenopus oocytes involves calcium-dependent chloride current. Neuron 4:53-60.

Lerma J, del Rio RM (1992) Chloride transport blockers prevent $\mathrm{N}$-methyl-D-aspartate receptor-channel complex activation. Mol Pharmacol 41:217-222.

Lerma J, Morales M, Ibarz JM, Somohano F (1994) Rectification properties and $\mathrm{Ca}^{2+}$ permeability of glutamate receptor channels in hippocampal cells. Pfluegers Arch 6:1080-1088.

Lingle C, Marder E (1981) A glutamate-activated chloride conductance on a crustacean muscle. Brain Res 212:481-488.

Maguire $G$, Werblin $F$ (1994) Dopamine enhances a glutamate-gated ionic current in OFF bipolar cells of the tiger salamander retina. $\mathrm{J}$ Neurosci 14:6094-6101.

Marder E (1987) Neurotransmitters and neuromodulators. In: The crustacean stomatogastric system (Selverston AI, Moulins M, eds). New York: Springer.

Marder E, Eisen JS (1984) Transmitter identification of pyloric neurons: electrically coupled neurons use different transmitters. J Neurophysiol 51:1345-1361.

Marder E, Weimann JM (1992) Modulatory control of multiple task processing in the stomatogastric nervous system. In: Neurobiology of motor programme selection: new approaches to mechanisms of behavioral choice (Kien J, McCrohan C, Winlow B, eds). Manchester: Manchester UP.

Marder E, Paupardin-Tritsch D (1978) The pharmacological properties of some crustacean neuronal acetylcholine, gamma-aminobutyric acid, and L-glutamate responses. J Physiol (Lond) 280:213-236.

Marder E, Skiebe P, Christie AE (1994) Multiple modes of network modulation. Verh Dtsch Zool Ges 87:177-184.

Miller C, White MM (1980) A voltage-dependent chloride conductance channel from Torpedo electroplax membrane. Ann NY Acad Sci 341: 534-551.

Miller JP, Selverston A (1979) Rapid killing of single neurons by irradiation of intracellularly injected dye. Science 206:702-704.

Miwa A, Ui M, Kawai N (1990) G protein is coupled to presynaptic glutamate and GABA receptors in lobster neuromuscular synapse. J Neurophysiol 63:173-180.

Mulloney B, Selverston AI (1974) Organization of the stomatogastric ganglion of the spiny lobster. I. Neurons driving the lateral teeth. J Comp Physiol 91:1-32.

Nakanishi S (1994) Metabotropic glutamate receptors: synaptic transmission, modulation, and plasticity. Neuron 13:1031-1037.

Nakanishi S, Masu M (1994) Molecular diversity and functions of glutamate receptors. Annu Rev Biophys Biomol Struct 23:319-348.

Newland CF, Cull-Candy SG (1992) On the mechanism of action of picrotoxin on GABA receptor channels in dissociated sympathetic neurones of the rat. J Physiol (Lond) 447:191-213.

Nusbaum MP, Weimann JM, Golowasch J, Marder E (1992) Presynaptic control of modulatory fibers by their neural network targets. J Neurosci 12:2706-2714.

Partridge LD, Sandquist M, Shaw T (1994) Flufenamate and mefenamate: effects on neuronal CAN channels. Soc Neurosci Abstr 20: 1522.

Pettit DL, Perlman S, Malinow R (1994) Potentiated transmission and prevention of further LTP by increased CaMKII activity in postsynaptic hippocampal slice neurons. Science 266:1881-1885.

Poronnik P, Ward MC, Cook DI (1992) Intracellular $\mathrm{Ca}^{2+}$ release by flufenamic acid and other blockers of the non-selective cation channel. FEBS Lett 296:245-248.

Pribilla I, Takagi T, Langosch D, Bormann J, Betz H (1992) The atypical M2 segment of the beta subunit confers picrotoxinin resistance to inhibitory glycine receptor channels. EMBO J 11:4305-4311.

Raditsch M, Witzemann V (1994) PVP-containing solutions for analysis of divalent cation-dependent NMDA responses in Xenopus oocytes. FEBS Lett 354:177-182.

Robinson RA, Stokes RH (1968) Electrolyte solutions: the measurement and interpretation of conductance, chemical potential, and diffusion in solutions of simple electrolytes, 2nd Ed. London: Butterworths.

Sanchez-Vives MV, Gallego R (1994) Calcium-dependent chloride current induced by axotomy in rat sympathetic neurons. J Physiol (Lond) 475:391-400

Sawada M, Hara N, Ito I, Maeno T (1984) Ionic mechanism of a hyperpolarizing glutamate effect on two identified neurons in the buccal ganglion of Aplysia. J Neurosci Res 11:91-103.

Schmidt KF, Kruse M, Hatt H (1994) Dopamine alters glutamate receptor desensitization in retinal horizontal cells of the perch (Perca fluviatilis). Proc Natl Acad Sci USA 91:8288-8291.

Swann JW, Sinback CN, Carpenter DO (1978) Dopamine-induced muscle contractions and modulation of neuromuscular transmission in Aplysia. Brain Res 157:167-172.

Thuma JB, Hooper SL (1994) Gross morphology of lobster pyloric neuron types. Soc Neurosci Abstr 20:1413.

Turrigiano GG, Marder E (1993) Modulation of identified stomatogastric ganglion neurons in primary cell culture. J Neurophysiol 69: 1993-2002.

Ueda Y, Steinberg RH (1994) Chloride currents in freshly isolated rat retinal pigment epithelial cells. Exp Eye Res 58:331-342.

Walker RJ (1976) The action of kainic acid and quisqualic acid on the glutamate receptors of three identifiable neurones from the brain of the snail, Helix aspersa. Comp Biochem Physiol C 55:61-67.

White MM, Aylwin M (1990) Niflumic and flufenamic acids are potent reversible blockers of $\mathrm{Ca} 2(+)$-activated $\mathrm{Cl}$ - channels in Xenopus oocytes. Mol Pharmacol 37:720-724.

Woodward RM, Polenzani L, Miledi R (1994) Effects of fenamates and other nonsteroidal anti-inflammatory drugs on rat brain GABAA receptors expressed in Xenopus oocytes. J Pharmacol Exp Ther 268: 806-817.

Yarowsky PJ, Carpenter DO (1976) Aspartate: distinct receptors on Aplysia neurons. Science 192:807-809. 